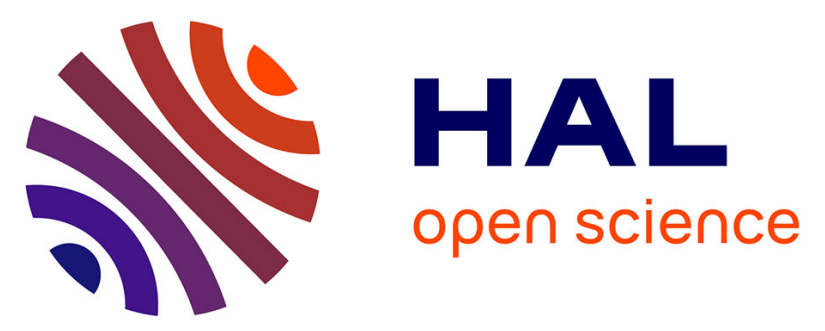

\title{
Origin of C2-C5 dicarboxylic acids in the European atmosphere inferred from year-round aerosol study conducted at a west-east transect
}

Michel Legrand, Susanne Preunkert, Tiago Oliveira, Casimiro Pio, S. Hammer, András Gelencsér, Anne Kasper-Giebl, Paolo Laj

\section{To cite this version:}

Michel Legrand, Susanne Preunkert, Tiago Oliveira, Casimiro Pio, S. Hammer, et al.. Origin of C2-C5 dicarboxylic acids in the European atmosphere inferred from year-round aerosol study conducted at a west-east transect. Journal of Geophysical Research: Atmospheres, 2007, 112 (D23S07), 1 à 14 p. 10.1029/2006JD008019 . insu-00377140

HAL Id: insu-00377140

https://hal-insu.archives-ouvertes.fr/insu-00377140

Submitted on 10 May 2021

HAL is a multi-disciplinary open access archive for the deposit and dissemination of scientific research documents, whether they are published or not. The documents may come from teaching and research institutions in France or abroad, or from public or private research centers.
L'archive ouverte pluridisciplinaire HAL, est destinée au dépôt et à la diffusion de documents scientifiques de niveau recherche, publiés ou non, émanant des établissements d'enseignement et de recherche français ou étrangers, des laboratoires publics ou privés. 


\title{
Origin of $\mathrm{C}_{2}-\mathrm{C}_{5}$ dicarboxylic acids in the European atmosphere inferred from year-round aerosol study conducted at a west-east transect
}

\author{
M. Legrand, ${ }^{1}$ S. Preunkert, ${ }^{1}$ T. Oliveira, ${ }^{2}$ C. A. Pio, ${ }^{2}$ S. Hammer, ${ }^{3}$ A. Gelencsér, ${ }^{4}$
}

A. Kasper-Giebl, ${ }^{5}$ and P. Laj ${ }^{6}$

Received 12 September 2006; revised 1 March 2007; accepted 27 March 2007; published 22 August 2007.

[1] An atmospheric study of $\mathrm{C}_{2}-\mathrm{C}_{5}$ dicarboxylic acids was conducted over two years at seven sites located from the Azores to eastern continental European sites. The lowest concentrations of total $\mathrm{C}_{2}-\mathrm{C}_{5}$ diacids are observed at the Azores (Portugal) and at $4360 \mathrm{~m}$ elevation in the Alps $\left(\sim 50 \mathrm{ng} \mathrm{m}^{-3}\right)$, and the highest $\left(400 \mathrm{ng} \mathrm{m}^{-3}\right)$ are observed at the rural K-puszta site (Hungary). Quasi-absent at surface sites, the seasonal cycle of total diacids is characterized by a pronounced summer maximum at elevated sites, the highest summer level $\left(510 \mathrm{ng} \mathrm{m}^{-3}\right)$ being observed at the forested mountain site of Schauinsland (Germany). Whatever site and season, oxalic acid is always the most abundant diacid with a relative abundance higher than $60 \%$. The climatology of $\mathrm{C}_{2}-\mathrm{C}_{5}$ diacids in Europe is discussed versus environmental conditions at sites (marine/ continental, rural/forested, boundary layer/free troposphere, and winter/summer). Observations are used to discuss the possible sources of $\mathrm{C}_{2}-\mathrm{C}_{5}$ diacids, with special emphasis on their primary versus secondary and natural versus anthropogenic origin. At surface sites in winter, fast secondary productions in wood burning plumes in addition to secondary production from volatile organic carbon (VOC) species emitted by vehicles seem to be important contributors. In summer the impact of anthropogenic sources is weakened and biogenic emissions from vegetation (unsaturated fatty acids, isoprene, oxygenated VOCs, and eventually monoterpenes) likely represent major precursors of diacids. At the Azores, diacids are not only related to long-range transport from continents but also to marine biogenic emissions from phytoplankton, particularly in summer.

Citation: Legrand, M., S. Preunkert, T. Oliveira, C. A. Pio, S. Hammer, A. Gelencsér, A. Kasper-Giebl, and P. Laj (2007), Origin of $\mathrm{C}_{2}-\mathrm{C}_{5}$ dicarboxylic acids in the European atmosphere inferred from year-round aerosol study conducted at a west-east transect, J. Geophys. Res., 112, D23S07, doi:10.1029/2006JD008019.

\section{Introduction}

[2] Numerous organic compounds significantly contribute to the aerosol load of the atmosphere and thus to the radiative forcing of climate. Among others the influence of organic aerosol on cloud droplet formation is a key point in evaluating effects of anthropogenic emissions on climate.

\footnotetext{
${ }^{1}$ Laboratoire de Glaciologie et Géophysique de l'Environnement du Centre National de la Recherche Scientifique, St. Martin d'Hères, France.

${ }^{2}$ Departamento de Ambiente e Ordenamento, Universidade de Aveiro, Aveiro, Portugal.

${ }^{3}$ Institut fur Umweltphysik, Ruprecht Karls-Universitat Heidelberg, Heidelberg, Germany.

${ }^{4}$ Air Chemistry Group of the Hungarian Academy of Sciences, University of Pannonia, Veszprém, Hungary.

${ }^{5}$ Institute for Chemical Technologies and Analytics, Vienna University of Technology, Vienna, Austria.

${ }^{6}$ Laboratoire de Météorologie Physique, Centre National de la Recherche Scientifique, Université Blaise Pascal, Aubières, France.

Copyright 2007 by the American Geophysical Union. 0148-0227/07/2006JD008019
}

In contrast to sulfate more uncertainties exist about organics and in particular for secondary organic aerosol species which are more oxygenated and hygroscopic than primary organic species [Saxena and Hildemann, 1996]. Among oxygenated organic species, dicarboxylic acids are probably the best quantified species, though they represent a small fraction of the total organic mass [Kawamura and Ikushima, 1993; Mader et al., 2004]. In addition to serve as CCN, glutaric acid, a $\mathrm{C}_{5}$ dicarboxylic acid found in the atmosphere, increases the CCN activation of major inorganic aerosol such as ammonium sulfate [Cruz and Pandis, 1997, 1998]. These findings suggest a potentially important role played by dicarboxylic acids on radiative forcing and stimulate their studies since the sources of diacids in the atmosphere remain poorly understood and quantified.

[3] Whatever the region (urban, rural, or marine), oxalic acid $\left(\mathrm{C}_{2}: \mathrm{HOOCCOOH}\right)$ is always found to be the most abundant diacid followed by succinic $\left(\mathrm{C}_{4}\right.$ : $\left.\mathrm{HOOC}\left(\mathrm{CH}_{2}\right)_{2} \mathrm{COOH}\right)$ and/or malonic $\left(\mathrm{C}_{3}\right.$ : $\mathrm{HOOCCH} \mathrm{COOH}_{2} \mathrm{CO}$ acid with concentrations of several hundreds of nanograms per cubic meter in urban regions [Kawamura and Ikushima, 1993; Kawamura and 
Kaplan, 1987] to a few tens of nanograms per cubic meter in remote marine boundary layer [Kawamura and Sakaguchi, 1999; Sempéré and Kawamura, 2003]. In Europe, the most continuous study of diacids was conducted over one year by Kerminen et al. [2000] at Helsinki $\left(60^{\circ} \mathrm{N}\right)$. Although available data on diacids are more sparse at midlatitudes in Europe, they tend to show that oxalic acid levels at rural sites are not considerably different from those at urban sites [Limbeck and Puxbaum, 1999; Röhrl and Lammel, 2001].

[4] Motor exhausts have been proposed to be primary sources of oxalic, malonic, succinic, and glutaric $\left(\mathrm{C}_{5}\right.$ : $\left.\mathrm{HOOC}\left(\mathrm{CH}_{2}\right)_{3} \mathrm{COOH}\right)$ acids [Kawamura and Kaplan, 1987; Grosjean, 1989]. Some of these diacids are also emitted by wood burning, particularly malonic acid (pine wood) and succinic acid (oak wood) [Rogge et al., 1998]. Note that until now no direct source of malic (hydroxysuccinic: $\mathrm{hC}_{4}$ : $\mathrm{HOOCCH}_{2} \mathrm{CHOHCOOH}$ ) and tartaric (dihydroxysuccinic: $\mathrm{dhC}_{4}$ : $\left.\mathrm{HOOC}(\mathrm{CHOH})_{2} \mathrm{COOH}\right)$ acids has been identified.

[5] Glutaric, succinic, and adipic $\left(\mathrm{C}_{6}: \mathrm{HOOC}\left(\mathrm{CH}_{2}\right)_{4} \mathrm{COOH}\right)$ acids have been identified in laboratory studies [Hatakeyama et al., 1985] as secondary organic aerosol products of the reaction of $\mathrm{O}_{3}$ with cyclohexene, a symmetrical alkene molecule similar to monoterpenes emitted by the biosphere. Kalberer et al. [2000] suggested that malonic and oxalic acids are also produced in the cyclohexene-ozone system.

[6] Unsaturated fatty acids with a double bond at the $\mathrm{C}_{9}$ position like cis-9-octadecenoic (oleic) acid are oxidized into $\mathrm{C}_{9}$ diacid (azelaic acid) and other products hereafter mainly oxidized into shorter diacids [Kawamura and Gagosian, 1987; Kawamura and Sakaguchi, 1999; Matsunaga et al., 1999]. These unsaturated acids which are abundant in marine phytoplankton and terrestrial higher plant leaves are also emitted by anthropogenic sources such as meat cooking [Rogge et al., 1991] and wood burning processes [Rogge et al., 1998].

[7] Warneck [2003] suggested that in the marine atmosphere clouds generate oxalic acid from glyoxal formed by oxidation of acetylene and glycolaldehyde formed by oxidation of ethene. Note that along these processes glyoxylic acid $(\mathrm{CHOCOOH})$ represents a key intermediate whereas diacids other than oxalic acid are not produced. Dealing with the formation of dicarboxylic acids in the continental atmosphere Ervens et al. [2004] also consider production of glyoxal from toluene and of glycolaldehyde from isoprene as well as aqueous phase reactions of adipic and glutaric acids produced by oxidation of cyclohexene. Recently more literature has become available on the formation of oxalic acid that includes also the oxidation of methylglyoxal, an oxidation product of toluene and isoprene, via intermediate steps involving pyruvic and acetic acids [Lim et al., 2005; Carlton et al., 2006]. Since this diacid production pathway also forms oligomers [Altieri et al., 2006], the knowledge of the sources of diacids is also of importance for the understanding of secondary organic aerosol formation.

[8] The relative contribution of primary and secondary sources of diacids in the atmosphere remains poorly understood. Even though it is agreed that they are likely to be mainly secondary in origin it is not known in which proportion their precursors come from anthropogenic and biogenic sources.
[9] In this work we report a year-round study of chemical composition of aerosols collected from mid-2002 to mid2004 at different sites located along a west-east transect in Europe, from the Azores to Hungary, including highelevation sites in the Alps. The climatology of $\mathrm{C}_{2}-\mathrm{C}_{5}$ diacids (oxalic, malic, malonic, succinic, tartaric, and glutaric) in Europe will be presented and discussed versus environmental conditions at sites (marine versus continental, rural versus forested, boundary layer versus free troposphere, and winter versus summer). The observations are used to discuss their possible sources in terms of primary versus secondary and natural versus anthropogenic origin. Discussions are done in the light of data on ${ }^{210} \mathrm{~Pb}$, inorganic ions like sulfate and potassium, and other organic species (total organic carbon, and selected organic tracers) gained in the framework of the CARBOSOL project which was dedicated to the study of the present and retrospective state of the organic versus inorganic aerosol over Europe [Legrand and Puxbaum, 2007].

\section{Sampling and Analysis}

[10] During the CARBOSOL project 540 high-volume aerosol samples were almost continuously collected at six sites along a west-east transect of $4000 \mathrm{~km}$ across Europe. From west to east the sites are: Azores denoted AZO (Terceira Islands, Portugal, $38^{\circ} \mathrm{N}, 27^{\circ} \mathrm{W}, 50 \mathrm{~m}$ above sea level (a.s.1.), oceanic conditions), Aveiro (AVE, Portuguese coast, $40^{\circ} \mathrm{N}, 8^{\circ} \mathrm{W}, 40 \mathrm{~m}$ a.sl., Atlantic coast), Puy de Dôme (PDD, center of France, $45^{\circ} \mathrm{N}, 2^{\circ} \mathrm{E}, 1450 \mathrm{~m}$ a.s.1., rural highlands), Schauinsland (SIL, mountain ridge of the Black Forest in southwestern Germany, $47^{\circ} \mathrm{N}, 07^{\circ} \mathrm{E}, 1205 \mathrm{~m}$ a.s.l., forested highlands), Sonnblick (SBO, high alpine site in Austria, $47^{\circ} \mathrm{N}, 12^{\circ} \mathrm{E}, 3106 \mathrm{~m}$ a.s.l., mountain peak in the central Alps) and K-puszta (KPZ, central plain of Hungary, $46^{\circ} \mathrm{N}, 19^{\circ} \mathrm{E}, 136 \mathrm{~m}$ a.s.1., plain surrounded by forests). More detailed descriptions of sites are given by Pio et al. [2007]. Weekly aerosol samplings on quartz fiber filters were carried at a flow rate of $20-60 \mathrm{~m}^{3} \mathrm{STP} \mathrm{h}^{-1}$ at each site from summer/fall 2002 to summer/fall 2004. After sampling, filter samples were wrapped in aluminum foil and immediately transported to the laboratory in charge of the sampling site, where they were stored at $-20^{\circ} \mathrm{C}$. Batches of sampled filters were divided into several fractions, enclosed into heated treated aluminum cylinders, and sent by express mail to the various laboratories participating in the analytical work where they were stored at cold temperature until analysis. In contrast to AZO, AVE, SBO and KPZ where a PM 2-2.5 inlet was deployed, at SIL and PDD a PM 10 inlet was used. That has to be kept in mind when comparing data related to coarse particles. Nevertheless, composition of size-segregated aerosol investigated during CARBOSOL (not presented in this paper) showed that, in PM10 aerosol, more than $90 \%$ of $\mathrm{EC}$ and $80 \%$ of $\mathrm{OC}$ are in PM2.5 particles.

[11] Additional samplings were achieved at Vallot (VO, $4360 \mathrm{~m}$ a.s.1., French Alps) by using an automatic aerosol sampler supplied by solar panels [Preunkert et al., 2002]. A year-round study of sulfate previously conducted there indicates that VO is the only European sampling site located in summer above the mixed layer [Preunkert et al., 2001]. From April 2002 to September 2003 aerosol studies included 
Table 1. Summer (S) and Winter (W) Concentrations of Total Organic Carbon (TC in Carbon Mass), Anthropogenic Sulfate, Non-Sea-Salt and Nondust Fraction of Potassium, Total C2-C5 Diacids (Total Mass), and Glyoxylic Acid at the CARBOSOL Sites ${ }^{\mathrm{a}}$

\begin{tabular}{|c|c|c|c|c|c|}
\hline Sites & $\mathrm{TC}, \mu \mathrm{gC} \mathrm{m}^{-3}$ & Anthropogenic $\mathrm{SO}_{4}, \mathrm{ng} \mathrm{m}^{-3}$ & Nss-ndust-K, $\mathrm{ng} \mathrm{m}^{-3}$ & Total $\mathrm{C} 2-\mathrm{C} 5, \mathrm{ng} \mathrm{m}^{-3}$ & Glyoxylic, $\mathrm{ng} \mathrm{m}^{-3}$ \\
\hline KPZ (S) & $5.6 \pm 1.9$ & $3602 \pm 1154$ & $110 \pm 85$ & $375 \pm 139$ & $9 \pm 7$ \\
\hline KPZ (W) & $8.9 \pm 4.9$ & $4767 \pm 3975$ & $303 \pm 204$ & $409 \pm 290$ & $38 \pm 43$ \\
\hline AVE (S) & $3.7 \pm 1.8$ & $3950 \pm 2330$ & $125 \pm 73$ & $374 \pm 213$ & $6 \pm 7$ \\
\hline AVE (W) & $8.8 \pm 4.4$ & $2110 \pm 1481$ & $201 \pm 99$ & $320 \pm 190$ & $11 \pm 7$ \\
\hline SIL (S) & $3.7 \pm 1.8$ & $2990 \pm 1378$ & $77 \pm 61$ & $507 \pm 257$ & $9 \pm 8$ \\
\hline SIL (W) & $1.6 \pm 1.0$ & $1440 \pm 1067$ & $44 \pm 35$ & $190 \pm 181$ & $8 \pm 7$ \\
\hline PDD (S) & $2.6 \pm 1.4$ & $1780 \pm 960$ & $37 \pm 23$ & $299 \pm 184$ & $13 \pm 15$ \\
\hline PDD (W) & $1.0 \pm 0.8$ & $757 \pm 720$ & $21 \pm 23$ & $112 \pm 129$ & $4 \pm 4$ \\
\hline SBO (S) & $1.6 \pm 1.0$ & $956 \pm 628$ & nd & $\sim 148^{\mathrm{b}}$ & $\sim 2^{\mathrm{b}}$ \\
\hline SBO (W) & $0.5 \pm 0.5$ & $376 \pm 314$ & nd & $\mathrm{Nd}$ & nd \\
\hline $\mathrm{VO}(\mathrm{S})^{\mathrm{c}}$ & 0.3 & 548 & 8 & 82 & 4 \\
\hline $\operatorname{VO}(S)^{d}$ & nd & $437 \pm 207$ & $7 \pm 4$ & $67 \pm 43$ & nd \\
\hline $\mathrm{VO}(\mathrm{W})^{\mathrm{d}}$ & nd & $145 \pm 65$ & $3 \pm 2$ & $14 \pm 9$ & nd \\
\hline AZO (S) & $0.4 \pm 0.2$ & $980 \pm 850$ & $15 \pm 18$ & $88 \pm 57$ & $0.7 \pm 0.7$ \\
\hline AZO (W) & $0.3 \pm 0.2$ & $333 \pm 444$ & $10 \pm 17$ & $43 \pm 46$ & $0.8 \pm 0.6$ \\
\hline
\end{tabular}

${ }^{\mathrm{a}} \mathrm{TC}$, sulfate, and potassium data are from Pio et al. [2007]. nd, not determined.

${ }^{\mathrm{b}}$ Estimated from a limited number of samples (see section 3 ).

${ }^{\mathrm{c}}$ Mean value of three high-volume filters collected at this site (see section 2).

${ }^{\mathrm{d}}$ Mean values observed on continuous low-volume sampling at this site.

$\mathrm{C}_{2}-\mathrm{C}_{5}$ diacids with the aim to document their levels above $4000 \mathrm{~m}$ elevation [Legrand et al., 2005]. The flow rate of the device is $3 \mathrm{~L}$ STP per minute and aerosol samples cover $7-10$ days in summer and 20 days in winter. Because of the limited energy supply available at VO no continuous high-volume aerosol sampling needed for investigation of other organic compounds was possible. However, intensive field campaigns were organized at the site in summer 2004 (25-26 May and 31 August to 3 September) and 3 quartz fiber filters were collected by sucking around $1000 \mathrm{~m}^{3} \mathrm{STP}$ of air with a high-volume sampler and analyzed for ions as well as for other organic compounds.

[12] Oxalate $\left({ }^{-} \mathrm{OOCCOO}^{-}\right)$, malonate $\left({ }^{-} \mathrm{OOCCH}_{2} \mathrm{COO}^{-}\right)$, succinate $\left({ }^{-} \mathrm{OOC}\left(\mathrm{CH}_{2}\right)_{2} \mathrm{COO}^{-}\right)$, malate $\left({ }^{-} \mathrm{OOCCH}_{2}\right.$ $\left.\mathrm{CHOHCOO}^{-}\right)$, tartarate $\left({ }^{-} \mathrm{OOC}(\mathrm{CHOH})_{2} \mathrm{COO}^{-}\right)$, and glutarate $\left({ }^{-} \mathrm{OOC}\left(\mathrm{CH}_{2}\right)_{3} \mathrm{COO}^{-}\right)$were quantified with a Dionex 600 chromatograph equipped with an AS11 separator column and a gradient pump system as detailed by Ricard et al. [2002]. Glyoxylic acid $\left(\mathrm{CHOCOO}^{-}\right)$, a monocarboxylic acid of interest for further discussions on the origin of diacids, was also investigated by using similar ion chromatography working conditions. For all dicarboxylic acids as well as glyoxylic acid the detection limit is close to $1 \mathrm{ng} \mathrm{m}^{-3}$ (from 0.5 to $1.3 \mathrm{ng} \mathrm{m}^{-3}$ ) and is related to the accuracy of the ion chromatography. For the low-volume aerosol sampling achieved at VO the detection limits are $0.5 \mathrm{ng} \mathrm{m}^{-3}$ for oxalic and malonic acids, and $0.1 \mathrm{ng} \mathrm{m}^{-3}$ for other dicarboxylic acids. Only the malonic acid levels in winter were there so low that they could not be always detected.

[13] The climatology of diacids in terms of sources will be discussed in the light of other information gained during the CARBOSOL project. They include ${ }^{210} \mathrm{~Pb}$, total (elemental and organic) carbon (TC), levoglucosan, different families of organic compounds investigated by using gas chromatography/mass spectrometer (GC-MS), as well as some inorganic species like sulfate, MSA, and potassium. Details on analytical methods deployed for analysis of these compounds are given by Pio et al. [2007, and references therein].

\section{Data Presentation}

[14] The total mass concentrations of $\mathrm{C}_{2}-\mathrm{C}_{5}$ diacids observed at the CARBOSOL sites are reported in Table 1 for winter (October to March) and summer (April to September) along with the levels of glyoxylic acid. Total organic carbon (TC), anthropogenic fraction of sulfate, and fraction of potassium not related to sea salt and dust emissions that will be used for discussions on origin of diacids, are also reported.

[15] The calculation of the anthropogenic fraction of sulfate, mainly secondarily produced from $\mathrm{SO}_{2}$ emissions, requires the knowledge of the amount of primary sulfate related to sea salt and dust emissions and of the biogenic one related to oxidation of DMS emitted by phytoplankton. As detailed by Pio et al. [2007], this was done by using sodium, calcium and methanesulfonate data. In this work we also use the fraction of potassium present in excess with respect to sea salt as well as dust material (denoted Nssndust-K). This potassium fraction is well representative of submicronic aerosol primarily emitted in the atmosphere during wood burning [Cachier et al., 1991]. As detailed by Pio et al. [2007] this fine fraction of potassium can be estimated from the total potassium by using sodium and calcium data.

[16] At VO in summer the composition of aerosol collected on the few available high-volume samples is compared in Table 1 with those continuously sampled with a low-volume sampler. The mean level of sulfate and total $\mathrm{C}_{2}-\mathrm{C}_{5}$ diacids of high-volume filters are very consistent with those of low-volume continuous sampling suggesting that the few high-volume aerosol samples collected in summer 2004 are well representative of mean summer conditions at that site.

[17] Measurements made on filters collected at SBO in summer 2003 surprisingly showed a mean total $\mathrm{C}_{2}-\mathrm{C}_{5}$ diacids $\left(30 \mathrm{ng} \mathrm{m}^{-3}\right.$ ) far lower than the one observed at 
VO (70-80 ng $\mathrm{m}^{-3}$, Table 1). Furthermore the commonly observed covariance between sulfate and diacids at mountain sites, partly driven by the seasonal change of atmospheric upward transport [Pio et al., 2007], is not observed $\left([\mathrm{Oxalic}\right.$ acid $]=0.01\left[\mathrm{SO}_{4}\right]$ with $\mathrm{R}^{2}=0.04$ at $\mathrm{SBO}$ instead of $\left[\right.$ Oxalic acid] $=0.1\left[\mathrm{SO}_{4}\right]$ with $\mathrm{R}^{2}=0.9$ at $\left.\mathrm{VO}\right)$. To investigate origin of the discrepancy (problem during sampling, storage or transport of pieces of filters) six filters collected at SBO in July/August 2003 were reanalyzed showing the expected good relationship between sulfate and diacids ([Oxalic acid] $=0.07\left[\mathrm{SO}_{4}\right]$ with $\mathrm{R}^{2}=0.96$ ). Whereas sulfate levels were similar, the mean oxalic acid level observed on the reanalyzed filters $\left(99 \mathrm{ng} \mathrm{m}^{-3}\right)$ is far higher than the mean value previously observed on the same filters $\left(19 \mathrm{ng} \mathrm{m}^{-3}\right)$. Thus it appears that diacids have been lost during storage and transport of pieces of filters dedicated to this study of ions. Among others one possibility is that airborne microbes (bacteria and fungi) have been introduced on pieces of filters since it was recently shown that bacteria use dicarboxylic acids as nutrients [Ariya et al., 2002]. Although the entire set of filters collected at SBO was not reanalyzed for diacids, on the basis of the relationship between sulfate and total diacids on the 6 reanalyzed filters and the mean sulfate level of $956 \mathrm{ng} \mathrm{m}^{-3}$ observed over the entire summer period, an estimate of the mean summer level of total diacids at SBO is reported in Table 1.

[18] The speciation of diacids observed at the different sites versus the season (Table 2) is summarized in Figure 1. The main features are a quasi absence of seasonality at surface sites (KPZ and AVE) contrasting with a well marked summer maximum at mountain sites (SIL, PDD and VO), a relatively large abundance of diacids at the forested site of SIL in summer, and a dominant presence of oxalic acid at

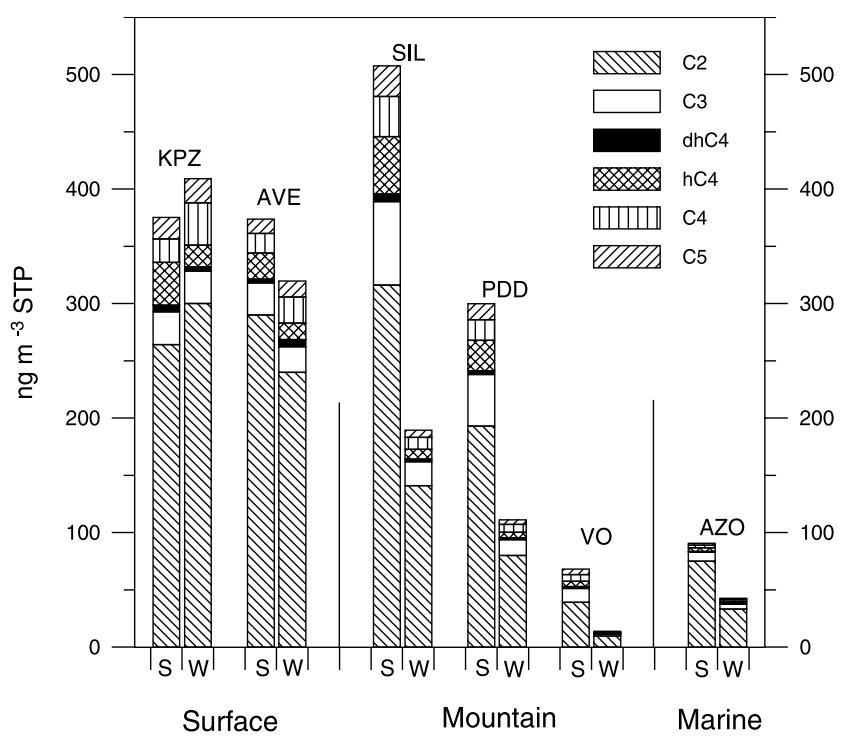

Figure 1. Mean summer (S) and winter (W) speciation of C2-C5 diacids observed at CARBOSOL sites: Surface sites (KPZ and AVE), mountain sites (SIL, PDD, and VO) and the marine $\mathrm{AZO}$ site. $\mathrm{C} 2$ is oxalic, $\mathrm{C} 3$ is malonic, dhC4 is tartaric, hC4 is malic, $\mathrm{C} 4$ is succinic, and $\mathrm{C} 5$ is glutaric acid. 
Table 3. Linear Relationships Between Diacids at KPZ, AVE, and AZO in Winter and Summer

\begin{tabular}{lll}
\hline \multicolumn{1}{c}{ Winter } & \multicolumn{1}{c}{ Summer } \\
\hline AVE & {$[\mathrm{Ox}]=8.1[\mathrm{Malon}]+61\left(\mathrm{R}^{2}=0.87\right)$,} & {$[\mathrm{Ox}]=5.9[\mathrm{malon}]+125\left(\mathrm{R}^{2}=0.70\right)$,} \\
& {$[\mathrm{Ox}]=4.3([\mathrm{Suc}]+[\mathrm{Mal}])+78\left(\mathrm{R}^{2}=0.80\right)$,} & {$[\mathrm{Ox}]=4.8([\mathrm{Suc}]+[\mathrm{Mal}])+117\left(\mathrm{R}^{2}=0.80\right)$,} \\
& {$[\mathrm{Suc}]=1.44[\mathrm{Mal}]\left(\mathrm{R}^{2}=0.73\right)$,} & {$[\mathrm{Suc}]=0.78[\mathrm{Mal}]\left(\mathrm{R}^{2}=0.73\right)$,} \\
$\mathrm{KPZ}$ & {$[\mathrm{Ox}]=12.7[\mathrm{Glu}]+63\left(\mathrm{R}^{2}=0.75\right)$} & {$[\mathrm{Ox}]=7.3[\mathrm{Glu}]+170\left(\mathrm{R}^{2}=0.45\right)$} \\
& {$[\mathrm{Ox}]=6.5[\mathrm{Malon}]+117\left(\mathrm{R}^{2}=0.80\right)$,} & {$[\mathrm{Ox}]=6.5[\mathrm{Malon}]+80\left(\mathrm{R}^{2}=0.69\right)$,} \\
& {$[\mathrm{Ox}]=3.8([\mathrm{Suc}]+[\mathrm{Mal}])+87\left(\mathrm{R}^{2}=0.90\right)$,} & {$[\mathrm{Ox}]=2.5([\mathrm{Suc}]+[\mathrm{Mal}])+121\left(\mathrm{R}^{2}=0.44\right)$,} \\
& {$[\mathrm{Suc}]=1.9[\mathrm{Mal}]\left(\mathrm{R}^{2}=0.75\right)$,} & {$[\mathrm{Suc}]=0.5[\mathrm{Mal}]\left(\mathrm{R}^{2}=0.53\right)$,} \\
& {$[\mathrm{Ox}]=9.2[\mathrm{Glu}]+107\left(\mathrm{R}^{2}=0.81\right)$} & {$[\mathrm{Ox}]=7.8[\mathrm{Glu}]+109\left(\mathrm{R}^{2}=0.54\right)$} \\
& {$[\mathrm{Ox}]=6.8[\mathrm{Malon}]+4\left(\mathrm{R}^{2}=0.67\right)$,} & {$[\mathrm{Ox}]=5.2[\mathrm{Malon}]+35\left(\mathrm{R}^{2}=0.55\right)$,} \\
& {$[\mathrm{Ox}]=10.7([\mathrm{Suc}]+[\mathrm{Mal}])\left(\mathrm{R}^{2}=0.82\right)$,} & {$[\mathrm{Ox}]=6.4([\mathrm{Suc}]+[\mathrm{Mal}])+43\left(\mathrm{R}^{2}=0.43\right)$,} \\
& {$[\mathrm{Suc}]=0.8[\mathrm{Mal}]\left(\mathrm{R}^{2}=0.77\right)$,} & {$[\mathrm{Suc}]=0.6[\mathrm{Mal}]\left(\mathrm{R}^{2}=0.60\right)$,} \\
& {$[\mathrm{Ox}]=41.5[\mathrm{Glu}]-4\left(\mathrm{R}^{2}=0.60\right)$} & {$[\mathrm{Ox}]=22.5[\mathrm{Glu}]+36\left(\mathrm{R}^{2}=0.44\right)$}
\end{tabular}

AZO. These differences aimed to explain the atmospheric budget of diacids in Europe.

\section{Origins of Diacids at Surface Continental Sites}

[19] The mean total mass concentration of $\mathrm{C} 2-\mathrm{C} 5$ diacids exhibits no significant seasonality at KPZ and AVE (Figure 1). That does not mean however that the strength of emissions is similar in winter and summer since, as suggested by ${ }^{210} \mathrm{~Pb}$ data [Hammer et al., 2007], stable conditions developing in winter at surface sites reduce the vertical mixing intensity at that season. Selecting filter samples corresponding to time periods over which ${ }^{222} \mathrm{Rn}$ activities $\left({ }^{222} \mathrm{Rn}\right.$ data gained by IUP Heidelberg during the CARBOSOL project will be discussed elsewhere) are lower than $5 \mathrm{~Bq} \mathrm{~m}^{-3}$ at AVE, we found a mean diacid level $30 \%$ higher in summer than in winter $\left(275 \mathrm{ng} \mathrm{m}^{-3}\right.$ instead of $208 \mathrm{ng} \mathrm{m}^{-3}$ ) whereas the mean ${ }^{222} \mathrm{Rn}$ activity of selected samples remains similar $\left(2.5 \mathrm{~Bq} \mathrm{~m}^{-3}\right.$ for summer and $2.7 \mathrm{~Bq} \mathrm{~m}^{-3}$ for winter samples). Therefore we have to keep in mind that KPZ and AVE sites may likely experience winter accumulation of diacids emitted by surrounding local to regional sources whereas in summer diacids would come from larger-scale emissions.

[20] Whatever the season, oxalic acid is the dominant diacid ( 70 to $80 \%$ of the $\mathrm{C} 2-\mathrm{C} 5$ sum, Table 2). Although the level of oxalic acid is always correlated to the ones of longer-chain diacids, the correlation coefficients are systematically weaker in summer than in winter, particularly with glutaric acid (Table 3). High values of correlation coefficients suggest that the $\mathrm{C} 2-\mathrm{C} 5$ diacids are either primarily emitted (or fast secondarily produced) together with a dominant fraction as oxalic acid or strongly connected to each other in a chain of reactions transforming glutaric acid into oxalic acid. Such a chain of reactions can take place in cloud water as reported in Figure 2. However, a good correlation between the different diacids would require almost identical reaction rates in the successive oxidation steps, otherwise ones would have accumulated and others would have been depleted, depending on age of aerosol and ambient conditions. That is not the case since $\mathrm{OH}$ aqueous phase reaction is thought to be more efficient on $\mathrm{C} 3$ and $\mathrm{C} 4$ diacids than on glutaric acid [Ervens et al., 2004]. With a rate constant of $1.10^{7} \mathrm{M}^{-1} \mathrm{~s}^{-1}$ for the $\mathrm{OH}$ reaction with glutaric acid $\left(5.10^{7} \mathrm{M}^{-1} \mathrm{~s}^{-1}\right.$ with succinic and malonic acids) and simulated aqueous phase concentrations of $\mathrm{OH}$ in June of $10^{-13} \mathrm{M}$ in early morning and late afternoon (5 $10^{-13} \mathrm{M}$ at noon), Ervens et al. [2004] showed that successive oxidation steps of $\mathrm{C} 5$ into shorter diacids efficiently proceed in summer. In winter the aqueous phase concentrations of $\mathrm{OH}$ would be lowered because of the decrease of its major sources (transfer of $\mathrm{OH}$ from the gas phase, aqueous phase photolysis of $\mathrm{H}_{2} \mathrm{O}_{2}$, reaction $\mathrm{H}_{2} \mathrm{O}_{2}+$ $\mathrm{Fe}^{2+} / \mathrm{Cu}^{+}$[Ervens et al., 2003a] following the decrease of sunlight and $\mathrm{H}_{2} \mathrm{O}_{2}$ level. Another change of the efficiency of $\mathrm{OH}$ reactions with diacids from winter to summer would be related to $\mathrm{pH}$ change since anions react faster than their acidic forms [Ervens et al., 2003b]. In order to evaluate seasonal change in $\mathrm{pH}$ of aerosol we examine the imbalance between cations $\left(\mathrm{Na}^{+}, \mathrm{NH}_{4}^{+}, \mathrm{K}^{+}, \mathrm{Mg}^{2+}\right.$, and $\left.\mathrm{Ca}^{2+}\right)$ and anions $\left(\mathrm{Cl}^{-}, \mathrm{NO}_{3}^{-}, \mathrm{SO}_{4}^{2-}\right.$, and $\mathrm{C} 2-\mathrm{C} 5$ dicarboxylates). Both at AVE and KPZ an imbalance between cations and anions $(\Delta \mathrm{C})$ representing less than $3 \%$ of the ionic budget of aerosol $(\Sigma)$ is found $\left(\Delta \mathrm{C}=-5 \mathrm{nEq} \mathrm{m}^{-3}\right.$ for $\Sigma=202 \mathrm{nEq} \mathrm{m}^{-3}$ at AVE, $\Delta \mathrm{C}=14 \mathrm{nEq} \mathrm{m}^{-3}$ for $\Sigma=$ $485 \mathrm{nEq} \mathrm{m}^{-3}$ at KPZ). The imbalance between cations and anions thus remains close to experimental errors in determining ionic species and points out the neutral character of aerosol at AVE and KPZ. Furthermore no significant change of the imbalance between cations and anions is seen from winter to summer. These considerations therefore suggest that the aqueous phase decays of longer into shorter diacids mainly depend on $\mathrm{OH}$ levels and are more efficient in summer than in winter. That is also supported by the larger abundance of succinic acid with respect to malic acid at KPZ in winter whereas the reverse is observed in summer (Table 3). Since no direct emissions have been identified for malic acid, likely formed by hydroxylation of succinic acid, this change of the partitioning in $\mathrm{C} 4$ diacids again signals more efficient aqueous phase $\mathrm{C} 2-\mathrm{C} 5$ reactions in summer than in winter.

[21] Since no primary source of diacids (vehicular emissions, wood combustion, meat cooking operations) emits oxalic acid alone, the y-intercept of the linear relationship between oxalic and malonic acid (mean value of $90 \mathrm{ng} \mathrm{m}^{-3}$ at AVE and $100 \mathrm{ng} \mathrm{m}^{-3}$ at KPZ, Table 3) suggests that, whatever the season, another production of oxalic acid, not related to the decay of longer diacids, occurs at the two sites. Referring to our knowledge of secondary productions of diacids (Figure 2) a possible production of oxalic acid may be the oxidation of glyoxylic acid. The $\mathrm{OH}$ rate constant of the aqueous phase oxidation of glyoxylate $\left(\mathrm{K}=3.10^{9} \mathrm{M}^{-1} \mathrm{~s}^{-1}\right.$ [Ervens et al., 2004]) is far larger that 


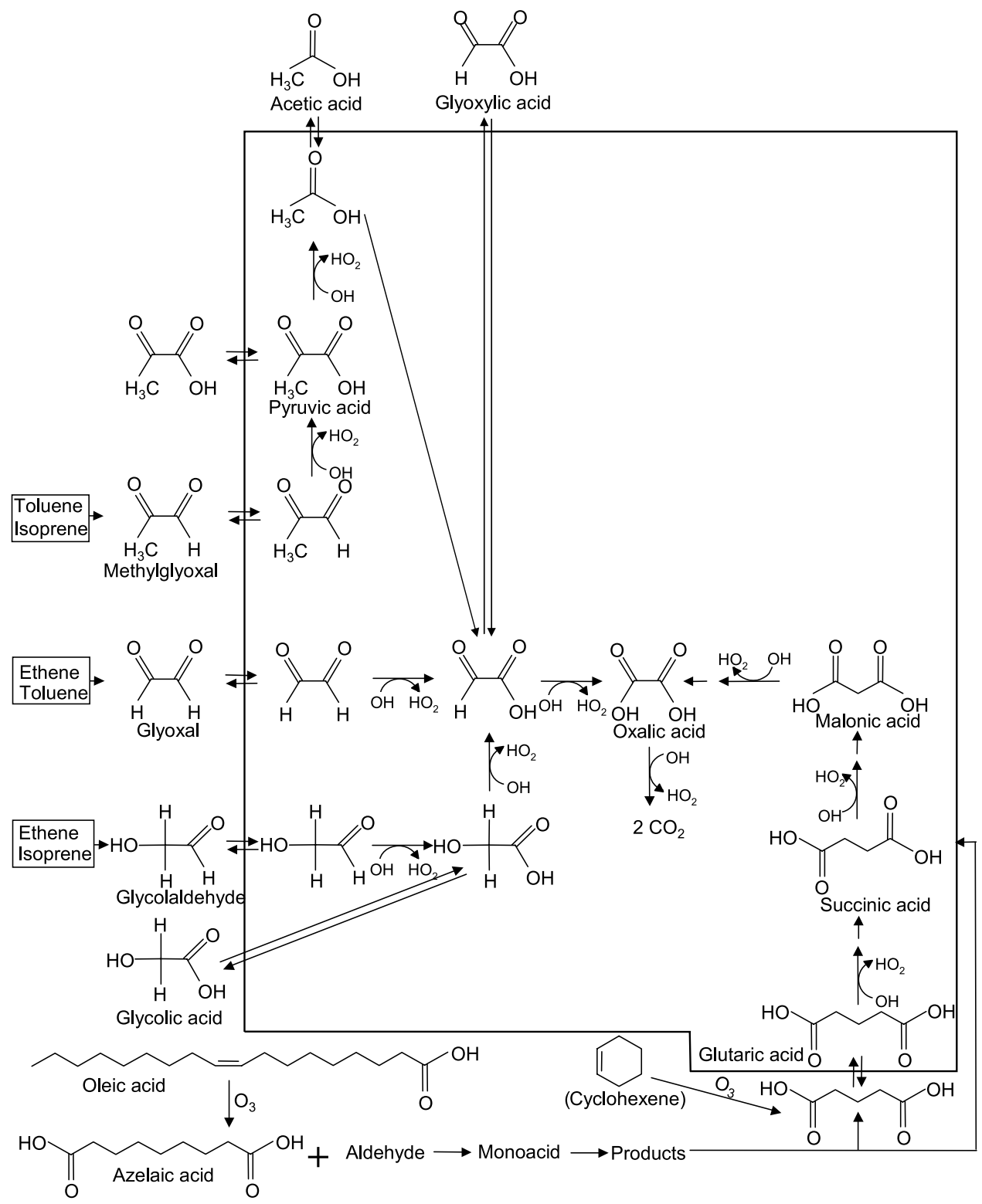

Figure 2. Multiphase organic chemistry producing $\mathrm{C} 2-\mathrm{C} 5$ diacids from key biogenic and anthropogenic precursors. The box refers to the aqueous phase. The figure is mainly adapted from Ervens et al. [2004] with modifications to account for the reaction pathway methylglyoxal/pyruvic acid/ acetic acid/glyoxylic acid suggested by Lim et al. [2005]. In addition to cyclohexene used by Ervens et al. [2004] as a model compound for symmetrical alkenes, following Matsunaga et al. [1999] we also report the oleic acid degradation into azelaic, $\mathrm{C} 4$ and $\mathrm{C} 5$ diacids.

of malonic acid, rendering possible this process even in winter. Even considering an aqueous phase concentration of $\mathrm{OH}$ as low as $10^{-14} \mathrm{M}$ in winter, the lifetime of glyoxylic acid is still short ( 9 hours) and the observed level of glyoxylic acid in winter $\left(10 \mathrm{ng} \mathrm{m}^{-3}\right.$ at AVE and $40 \mathrm{ng} \mathrm{m}^{-3}$ at KPZ, Table 1) strongly supports the importance of this pathway for the budget of oxalic acid.

[22] In summary whereas in summer aqueous secondary productions of oxalic acid are expected to take place both via glyoxylic acid and decays of higher diacids, in winter only the oxidation of glyoxylic acid appears to be an important secondary source of oxalic acid whereas a primary source (or fast secondary production) of oxalic acid and $\mathrm{C} 3-\mathrm{C} 5$ diacids exist. In the following we discuss the origin of primary and secondary sources versus the season.

\subsection{Origin in Winter}

[23] The averaged winter $\mathrm{C} 2-\mathrm{C} 5$ diacid level reaches $320 \mathrm{ng} \mathrm{m}^{-3}$ at AVE and $409 \mathrm{ng} \mathrm{m}^{-3}$ at KPZ (Table 1). Oxalic acid is the dominant diacid $(75 \%$ of the total mass of $\mathrm{C} 2-\mathrm{C} 5$, Table 2) and is well correlated to longer-chain diacids (Table 3).

[24] The y-intercept of the linear relationship between oxalic and malonic acid (60 $\mathrm{ng} \mathrm{m}^{-3}$ at AVE and $120 \mathrm{ng} \mathrm{m}^{-3}$ at KPZ, Table 3) suggests that the oxidation of glyoxylic 
Table 4. Relationships Between Diacids and nss-ndust-K at KPZ and AVE in Winter

\begin{tabular}{ll}
\hline Site & \multicolumn{1}{c}{ Relationships } \\
\hline KPZ & {$[\mathrm{Glu}]=0.06[$ nss-ndust-K $]+0\left(\mathrm{R}^{2}=0.76\right)$,} \\
& {$[\mathrm{Suc}]=0.11[$ nss-ndust-K $]+1\left(\mathrm{R}^{2}=0.74\right)$,} \\
& {$[\mathrm{Malon}]=0.05[$ nss-ndust-K $]+10\left(\mathrm{R}^{2}=0.17\right)$,} \\
& {$[\mathrm{Ox}]=0.44[$ nss-ndust-K $]+146\left(\mathrm{R}^{2}=0.30\right)$} \\
& {$[\mathrm{Glu}]=0.08[$ nss-ndust-K $]-1\left(\mathrm{R}^{2}=0.64\right)$,} \\
& {$[\mathrm{Suc}]=0.13[$ nss-ndust-K $]-3\left(\mathrm{R}^{2}=0.56\right)$,} \\
& {$[\mathrm{Malon}]=0.09[$ nss-ndust-K $]+4\left(\mathrm{R}^{2}=0.32\right)$,} \\
& {$[\mathrm{Ox}]=0.90[$ nss-ndust-K $]+60\left(\mathrm{R}^{2}=0.40\right)$} \\
\hline
\end{tabular}

acid may contribute to $25 \%$ and $40 \%$ of the level of oxalic acid at AVE and KPZ, respectively. Assuming that biogenic emissions of isoprene are low at that season, a possible source of glyoxylic acid may be the oxidation of toluene and ethene emitted by vehicles. Some n-alkanes can be used to trace back vehicular emissions. In urban areas n-alkanes ranging from $\mathrm{C} 23$ to $\mathrm{C} 34$ are mainly emitted by fossil fuel combustion and plant waxes. N-alkanes (C23-C34) were measured during the CARBOSOL project by Oliveira et al. [2007]. The concentrations of anthropogenic n-alkanes (C23-C34) calculated by subtracting the contribution of wax n-alkanes (taken as $\mathrm{Cn}-0.5 *\left(\mathrm{C}_{\mathrm{n}-1}+\mathrm{C}_{\mathrm{n}+1}\right)$, Oliveira et al. [2007]) to total n-alkanes are of $15 \mathrm{ng} \mathrm{m}^{-3}$ at AVE and $32 \mathrm{ng} \mathrm{m}^{-3}$ at KPZ in winter. To date similar calculations done on concentrations of individual C23 to C34 reported on a seasonal basis at the large city of Los Angeles by Rogge et al. [1993] indicate there a mean winter concentration of anthropogenic n-alkanes (C23-C34) of $67 \mathrm{ng}$ $\mathrm{m}^{-3}$. From that it can be concluded that KPZ, and to a lesser extent AVE, are significantly impacted by vehicular emissions that represent indeed a plausible source of oxalic acid via glyoxylic acid produced by the oxidation of toluene and ethene at the two sites in winter.

[25] As discussed above it is likely that in winter the decay of $\mathrm{C} 5$ in the aqueous phase will not contribute to the observed $\mathrm{C} 2-\mathrm{C} 4$ diacids at surface sites. If correct, a primary source of diacids may contribute to the level of C3-C5 diacids and to about two thirds of that of oxalate. Primary sources of $\mathrm{C} 2-\mathrm{C} 5$ include wood burning, vehicular exhausts and meat cooking operations but their significance is not well established. First the importance of vehicular exhaust for the $\mathrm{C} 2-\mathrm{C} 5$ atmospheric budget remains unclear. Vehicles, particularly diesel-powered engines, were found to emit significant amounts of $\mathrm{C} 2-\mathrm{C} 5$ diacids with a dominance of oxalic acid, 3 times less succinic acid, and 6 times less malonic and glutaric acids [Kawamura and Kaplan, 1987]. However, a chemical mass balance receptor model applied by Schauer et al. [1996] to the Los Angeles basin indicated that malonic acid is there related to wood burning, succinic and glutaric acids from both meat cooking and wood burning, and no significant contribution from vehicular emissions is found for these three diacids. Note however that the most abundant diacid, oxalic acid, was not apportioned by Schauer et al. [1996]. Although based on one test, the distribution of diacids in diesel engine exhaust observed by Kawamura and Kaplan [1987] is rather consistent with the slopes of linear relationships between oxalic and other diacids observed in winter at KPZ (Table 3), with a dominance of oxalic on C4 diacids, the latter being dominant with respect to both malonic and glutaric acids. However, a rather similar distribution of diacids dominated by oxalic, followed by succinic and glutaric acids was also reported in biomass burning plumes.

[26] Levoglucosan analysis made during CARBOSOL on monthly pooled filters [Puxbaum et al., 2007] indicate winter levels of $600 \mathrm{ng} \mathrm{m}^{-3}$ and $1000 \mathrm{ng} \mathrm{m}^{-3}$ at KPZ and AVE, respectively, suggesting high contribution of biomass smoke to organic matter at these sites in winter. Wood burning experiments have shown that C3-C5 diacids are present in biomass burning plumes [Rogge et al., 1998] but unfortunately oxalic acid was not documented. As far as we know the most complete data set on $\mathrm{C} 2-\mathrm{C} 5$ diacids in wood burning plumes is from Gao et al. [2003] on savanna fires. In smoke aerosols collected directly over the fire the authors found a large amount of potassium $\left(13,810 \mathrm{ng} \mathrm{m}^{-3}\right)$ and some diacids among which oxalic $\left(750 \mathrm{ng} \mathrm{m}^{-3}\right)$ dominates succinic $\left(470 \mathrm{ng} \mathrm{m}^{-3}\right)$ and glutaric acid $\left(300 \mathrm{ng} \mathrm{m}^{-3}\right)$. Using potassium to account for the dilution of the plumes Gao et al. [2003] showed that the concentrations of glutaric, succinic and oxalic acids strongly increased after $40 \mathrm{~min}$ of aging. For instance the glutarate to potassium ratio, close to $1 \%$ reached $15 \%$ after $40 \mathrm{~min}$. A similar increase is observed for the oxalate to potassium ratio, $2 \%$ over the fire and $25 \%$ after $40 \mathrm{~min}$. This formation of diacids during the initial aging of smoke aerosol was attributed to fast secondary productions in the smoke plume. Even higher enrichment of diacids with respect to potassium have been observed in long-range transported boreal wildfire smokes in summer with ratios of oxalate and succinate to potassium of 10 and 5, respectively [Sillanpää et al., 2005]. In this latter case, it is clear that, during the few days aging of the air in summer, aqueous phase reactions of diacids have proceeded. In order to evaluate to what extent wood burning (fast secondary productions and primary emissions) is a source of diacids at AVE and KPZ, we report in Table 4 the correlation between diacids and nss-ndust-potassium levels observed in winter. Glutaric and succinic acids are well correlated with nssndust-K and the slopes of the linear relationship $(\sim 0.1)$ are similar to those observed by Gao et al. [2003] during the initial aging of smoke aerosol (0.15). Furthermore the quasinul y-intercepts of correlations suggest that glutaric and succinic acids are strongly related to the emissions of nssndust-potassium. The slope of the relationship between oxalic acid and nss-ndust-potassium which ranges from 0.4 at KPZ to 0.9 at AVE are higher than the oxalate to potassium ratio found by Gao et al. [2003] after $40 \mathrm{~min}$ of aging of the smoke plume. Interestingly the y-intercepts of the correlation between oxalic acid and nss-ndust-potassium are close to those of the correlation between malonate and oxalate, consistently pointing out the existence of the secondary production of oxalic acid from glyoxylic acid. The case of malonic acid appears more complex with levels still rather well correlated to those of nss-ndust-potassium at AVE but not at KPZ. Gao et al. [2003] pointed out the singularity of malonic acid with respect to other diacid, being most of the time absent from the smoke plumes. Reversely, malonic acid was found to be the most abundant C3-C5 diacids emitted by pine wood burning [Rogge et al., 1998]. Oliveira et al. [2007] showed a far larger level of dehydroabietic acid, a resinic acid emitted by the combustion of pine, at AVE than KPZ in winter $\left(90 \mathrm{ng} \mathrm{m}^{-3}\right.$ instead 
of $15 \mathrm{ng} \mathrm{m}^{-3}$ ) which may explain the better correlation between malonic acid and wood smoke compounds at AVE than at KPZ.

[27] Finally, the oxidation of unsaturated fatty acids such as oleic acid mainly emitted by meat cooking and wood burning [Rogge et al., 1991, 1998] may be another secondary source of diacids in winter. Once emitted in the atmosphere oleic acid is rapidly destroyed, producing azelaic acid and other products which are further oxidized into glutaric and succinic acid (Figure 2). Schauer et al. [1996] found that at Los Angeles succinic and glutaric acids are related to both wood burning and meat cooking. Although oleic acid has been observed at a significant level in winter, particularly at KPZ (5.7 $\mathrm{ng} \mathrm{m}^{-3}$ [Oliveira et al., 2007]), its level remains far lower than that in Los Angeles $\left(40 \mathrm{ng} \mathrm{m}^{-3}\right.$ [Rogge et al., 1993]).

\subsection{Origin in Summer}

[28] At KPZ and AVE the level of anthropogenic n-alkanes estimated by Oliveira et al. [2007] decreases in summer compared to winter $\left(8 \mathrm{ng} \mathrm{m}^{-3}\right.$ instead $15 \mathrm{ng} \mathrm{m}^{-3}$ at AVE and $11 \mathrm{ng} \mathrm{m}^{-3}$ instead of $32 \mathrm{ng} \mathrm{m}^{-3}$ at KPZ). That likely reflects a more efficient dispersion of pollutants emitted at a regional scale by vehicular traffic. This more efficient dispersion of vehicular emissions would also lead to a decrease of the $y$-intercept of the relationship between oxalic and malonic acids from winter to summer, following the expected decrease of toluene and ethene. That is not the case with a y-intercept of the relationship between oxalic and malonic acids of $80 \mathrm{ng} \mathrm{m}^{-3}$ (instead of $117 \mathrm{ng} \mathrm{m}^{-3}$ in winter) at KPZ and $125 \mathrm{ng} \mathrm{m}^{-3}$ (instead of $61 \mathrm{ng} \mathrm{m}^{-3}$ in winter) at AVE (Table 3). Isoprene, whose emissions are far larger in summer than in winter, would be the main precursor of glyoxylic acid in summer thereafter oxidized into oxalic acid (Figure 2).

[29] The level of levoglucosan is decreased by a factor of 10 in summer $\left(\sim 70 \mathrm{ng} \mathrm{m}^{-3}\right)$ compared to winter at AVE and KPZ [Puxbaum et al., 2007]. The total C2-C5 diacid level not related to the oxidation of glyoxylic acid into oxalic acid (i.e., the sum of $\mathrm{C} 3-\mathrm{C} 5$ diacids plus the $\mathrm{C} 2$ level of which the $y$-intercept of the correlation between malonic and oxalic acid has been subtracted) reaches $290 \mathrm{ng} \mathrm{m}^{-3}$ at $\mathrm{KPZ}$ and $260 \mathrm{ng} \mathrm{m}^{-3}$ at AVE in winter. Similar values are still found in summer $\left(295 \mathrm{ng} \mathrm{m}^{-3}\right.$ at KPZ and $250 \mathrm{ng} \mathrm{m}^{-3}$ at AVE) suggesting that important sources of $\mathrm{C} 2-\mathrm{C} 5$ other than wood burning exist at that season. As discussed later in section 6 biogenic emissions from vegetation would represent a large source of glutaric acid at surface sites in summer and as discussed above glutaric acid can be oxidized into shorter-chain diacids via aqueous phase reactions at that season. Preceding discussions lead to the conclusion that in summer diacids are mainly secondarily produced. This conclusion is well supported by an example of the size distribution of diacids in summer reported in Figure 3, showing the accumulation of oxalic acid (i.e., the end product) in more aged particles that also contain more sulfate.

[30] In conclusion, at surface sites regional emissions from vehicles (toluene and ethene oxidized via glyoxylic acid into oxalic acid) and wood burning (fast secondary productions in the plumes) seem to be the major sources of diacids in winter. In summer the contribution of these anthropogenic processes is weakened but the contribution of biogenic emissions becomes important. Among biogenic precursors of diacids we suspect isoprene via the oxidation of glyoxylic acid but also other compounds leading to the production of $\mathrm{C} 3-\mathrm{C} 5$ diacids as will be discussed in section 6 .

\section{Changes of Diacids Versus Elevation Over Europe}

[31] As seen in Table 1, the total concentration of diacids strongly decreased with altitude in winter (a factor of 26 between the surface sites of KPZ and AVE and the high elevated alpine VO site). The corresponding decrease of anthropogenic sulfate is similar (a factor of 24) but lower than the one of non-sea-salt-non-dust potassium (a factor of 80 ). The relatively lower decrease of diacids and sulfate with height compared to the one of non-sea-salt-non-dust potassium, a species in submicron particles primarily emitted in the atmosphere, tends to suggest that a weak photochemical production of diacids takes place throughout a large part of the troposphere similarly to the production of sulfate from $\mathrm{SO}_{2}$.

[32] In summer the decrease with height is less pronounced than in winter for all species with a factor of 5.5 for total diacids, 8.5 for sulfate, and 17 for nss-non-dust-K (Table 1). This is first due to a more efficient upward transport of air masses from the boundary layer in summer than in winter, as confirmed by radioisotope data [Pio et al., 2007]. In addition, the weaker vertical decrease of diacids and sulfate than those of a primary species like nss-nondust-K points out the existence of secondary production of sulfate and diacids. The weaker decrease of diacids than sulfate, as already discussed by Legrand et al. [2005], suggests a faster mass formation rate of sulfate than diacids in agreement with the finding of Ervens et al. [2004]. On the basis of the extended data set of this study, in the following we discuss further photochemical productions of diacids.

[33] In Figure 4 we first compare the changes with altitude for midsummer conditions (June to August) between total diacids and other species like potassium and sulfate. We here have discarded data from SIL which are very particular with respect to diacids as will be discussed in section 7. From the surface to $4360 \mathrm{~m}$ elevation the level of primary specie (potassium) decreases exponentially by a factor 11 whereas the ones of sulfate and total diacids only decrease by a factor of 8 and 4 , respectively.

[34] Figure 5 shows important differences in vertical profile of the individual diacids. From the surface to $1500 \mathrm{~m}$ elevation glutaric and C4 diacids remain unchanged whereas oxalic acid decreases but to a lesser extent than a primary specie. The decrease between the surface and $4300 \mathrm{~m}$ elevation is weaker for C4-C5 diacids (glutaric, succinic, and malic) than for oxalic acid (a factor of to 2 to 3 instead of 5.7). As a result, although being the end product of oxidation processes, oxalic acid is still the major diacid at $4360 \mathrm{~m}$ elevation but its contribution to total diacids $(60 \%)$ becomes weaker there than at lower elevation $(\sim 70 \%)$. This finding of a weakened contribution of oxalic to the total mass of diacids when aerosol has experienced enough cloud cycles to reach steady state is in agreement with simulations 

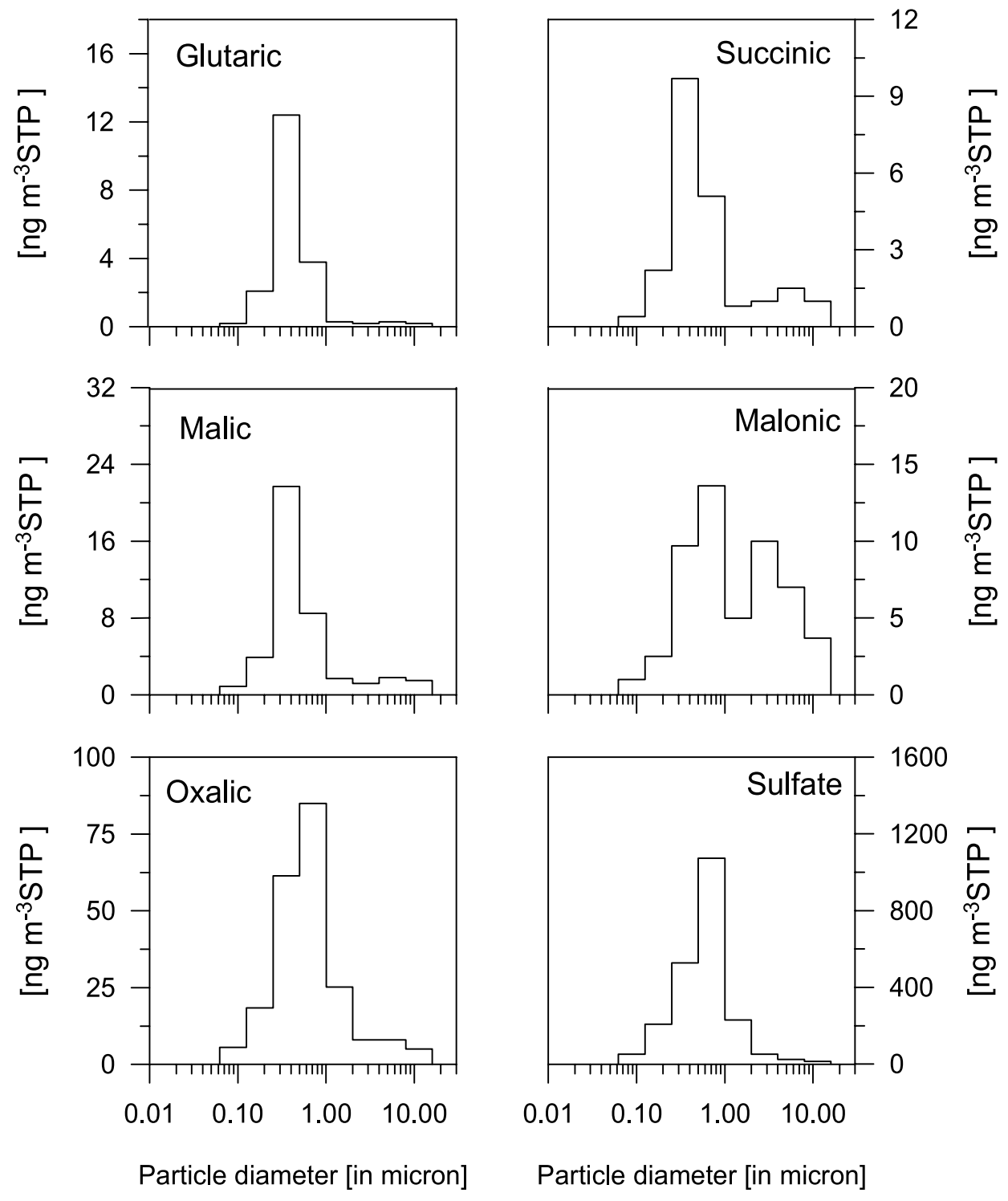

\section{Particle diameter [in micron]}

Figure 3. Mass size distribution of $\mathrm{C} 2-\mathrm{C} 5$ diacids and sulfate of aerosol collected from 19 to 26 July 2004 at KPZ by using a Berner impactor.

from Ervens et al. [2004] who point out that the oxidation of oxalic acid into $\mathrm{CO}_{2}$ is faster than its production from malonic acid. Note that malonic acid is only decreased by a factor of 1.6 at $4300 \mathrm{~m}$ elevation with respect to the surface and exhibits a well marked maximum at $1500 \mathrm{~m}$ elevation. The cause of this maximum is likely due to the cutoff of $10 \mu \mathrm{m}$ used at PDD (i.e., at $1500 \mathrm{~m}$ elevation) instead of $2.5 \mu \mathrm{m}$ at other sites. Indeed, at seen in Figure 3, malonic acid is the only diacid present in the submicrometer fraction.

\section{Diacids at the Forested SIL Site in Summer}

[35] In summer anthropogenic sulfate is slightly lower at SIL than at KPZ whereas diacids are more abundant at SIL than at KPZ (Table 1). The increase of individual diacids between the two sites is stronger for longer-chain diacids ( $40 \%$ for glutaric, $50 \%$ for succinic plus malic, and $250 \%$ for malonic acid) than for oxalic acid (only 24\%) (Table 2). The $y$-intercept of the relationship between oxalic and malonic acids is also higher at SIL than at $\mathrm{KPZ}\left(150 \mathrm{ng} \mathrm{m}^{-3}\right.$ instead of $80 \mathrm{ng} \mathrm{m}^{-3}$ ). It is thus clear that a strong source of diacids, particularly of $\mathrm{C} 3-\mathrm{C} 5$, is located nearby SIL.

[36] At SIL most of diacids are significantly correlated with the temperature with a better fit when concentrations are expressed as an exponential rather than linear function of the temperature. The correlation coefficient is better for glutaric acid $\left(\mathrm{R}^{2}=0.5\right)$ than for succinic $\left(\mathrm{R}^{2}=0.4\right)$ and malonic $\left(\mathrm{R}^{2}=0.15\right)$ and becomes again better with oxalic acid $\left(R^{2}=0.3\right)$. Efficient vertical mixing may coincide with high temperature and drive the preceding covariance. However, ${ }^{210} \mathrm{~Pb}$ activities provided by Hammer et al. [2007] reveal a very poor correlation with levels of diacids $\left(\mathrm{R}^{2}=\right.$ 0.00 with glutaric acid, for instance) on summer samples at SIL.

[37] The temperature dependence of diacid levels likely reflects their biogenic origins. The relatively large y-intercept of the relationship between oxalic and malonic acids at SIL compared to other sites confirms the role of isoprene on the 

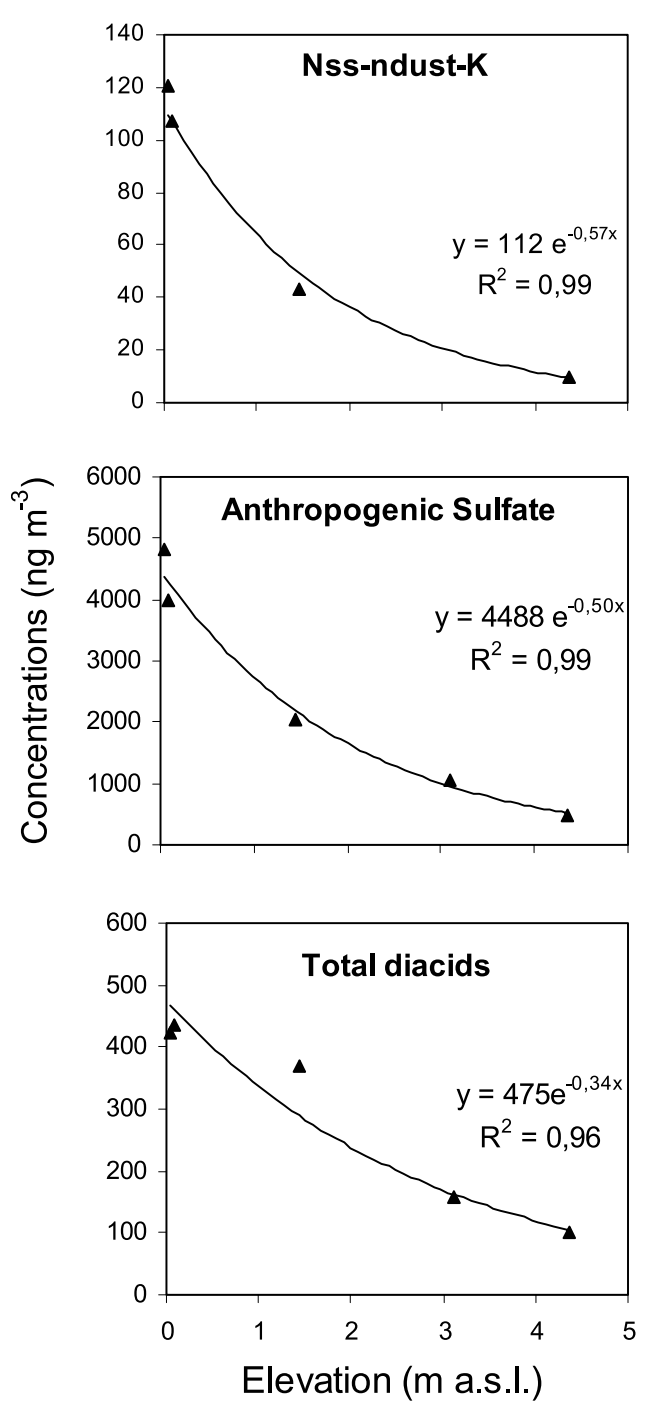

Figure 4. Exponential decreases of the level of non-seasalt-non-dust potassium, anthropogenic sulfate, and total diacids versus elevation under midsummer conditions (June-August). The non-sea-salt-non-dust potassium level at SBO is not reported for because of a calcium contamination [see Pio et al., 2007].

budget of oxalic acid since the spatial distribution of estimated isoprene emissions in Europe shows highest emissions in the area located $200 \mathrm{~km}$ west of SIL, in the east flank of France [Simpson et al., 1995]. In this area isoprene emissions are as high as 1.5 to 2.5 tons $\mathrm{km}^{-2} \mathrm{yr}^{-1}$ compared to 0.6 to 1.0 tons $\mathrm{km}^{-2} \mathrm{yr}^{-1}$ in the vicinity of KPZ. Furthermore the presence of acetic acid which may also be further oxidized into glyoxylic acid (Figure 2) was mainly attributed to direct emissions from vegetation and forest in France [Legrand et al., 2003].

[38] The relatively large abundance of $\mathrm{C} 3-\mathrm{C} 5$ diacids at SIL with respect to KPZ remains less clear. Among C2-C5 diacids, only glutaric acid exhibits a significant dependence to both temperature and ozone levels whereas other diacids are only significantly correlated to temperature. The double dependence of glutaric acid to $\mathrm{O}_{3}$ levels and $\mathrm{T}$ is illustrated in Figure 6. The good relationship between glutaric acid and ozone levels $\left(\mathrm{R}^{2}=0.34\right)$ suggests that glutaric acid is produced from the oxidation of a biogenic compound by ozone. Oleic acid, an unsaturated fatty acid present in tree leafs, is a plausible candidate as suggested by laboratory experiments which show that ozone reacts on oleic acid to form azelaic acid as a dominant product and shorter diacids, in particular C4-C6 [Matsunaga et al., 1999]. However, a larger abundance of azelaic acid than glutaric acid is expected which is not observed at SIL $\left(2.4 \mathrm{ng} \mathrm{m}^{-3}\right.$ of azelaic acid [Oliveira et al., 2007] against $27 \mathrm{ng} \mathrm{m}^{-3}$ of glutaric acid). Furthermore the similar level of oleic acid at SIL and KPZ (1.6 ng m ${ }^{-3}$ [Oliveira et al., 2007]) cannot explain alone the larger abundance of $\mathrm{C} 2-\mathrm{C} 5$ diacids found at SIL compared to KPZ.

[39] The site of SIL is located in the dense forested area of the Black Forest $\left(\sim 8000 \mathrm{~km}^{2}\right)$ which emits large amounts of monoterpenes in summer. At the scale of West Germany monoterpene emissions are far larger $\left(0.7\right.$ tons $\left.\mathrm{yr}^{-1} \mathrm{~km}^{-2}\right)$ than in France $\left(0.22\right.$ tons $\left.\mathrm{yr}^{-1} \mathrm{~km}^{-2}\right)$ or Hungary $(0.065$ tons $\mathrm{yr}^{-1} \mathrm{~km}^{-2}$ ) for instance [Simpson et al., 1999]. Although secondary production of organic aerosol from monoterpenes is controlled by $\mathrm{O}_{3}$ [Griffin et al., 1999], $\mathrm{C} 2-\mathrm{C} 5$ diacids are not predicted to be formed here. The glutaric acid level increases exponentially with temperature (Figure 6) with a slope $\mathrm{dln}[\mathrm{Glu}] / \mathrm{dT}$ of $0.094^{\circ} \mathrm{C}^{-1}$. This value of the slope is very similar to the mean slope recommended in the literature to describe the temperature dependence of emissions of OVOCs (volatile organic compounds others than isoprene and monoterpenes) and monoterpenes $\left(0.09^{\circ} \mathrm{C}^{-1}\right.$ [Kesselmeier and Staudt, 1999]). Although having been less investigated than isoprene and monoterpenes, vegetation emissions of OCOVs are known to include a large spectrum of oxygenated compounds among which several species may act as precursors of diacids. Emissions of OVOCs by vegetation are higher in west Germany than in France $\left(0.5\right.$ tons $\mathrm{yr}^{-1} \mathrm{~km}^{-2}$ instead of 0.2 tons $\mathrm{yr}^{-1} \mathrm{~km}^{-2}$ ). The observed good correlation between glutaric acid level and temperature at SIL may be caused by OVOC emissions. In addition, since there are liquid phase processes that are not yet understood we cannot totally exclude that some of them can produce diacids like glutaric acid. As an example Altieri et al. [2006] recently suggested that pyruvic acid can form oligomers in cloud water and from them oxalic acid. Although not yet documented we cannot exclude that oligomers formed from terpene oxidation products formed longer diacids, thus explaining the observed dln [Glu]/dT slope of $0.094^{\circ} \mathrm{C}^{-1}$.

\section{Origins of Diacids at the Marine AZO Site}

[40] Total $\mathrm{C} 2-\mathrm{C} 5$ diacids are around 5 times less abundant at AZO than at AVE $\left(65 \mathrm{ng} \mathrm{m}^{-3}\right.$ instead of $350 \mathrm{ng}$ $\mathrm{m}^{-3}$, Table 1) and slightly higher than values previously reported for very remote marine boundary layer, $25-45 \mathrm{ng}$ $\mathrm{m}^{-3}$ in the tropical Pacific ocean [Kawamura and Usukura, 1993; Kawamura and Sakaguchi, 1999]. As seen in Table 2, the ratio of total diacids-C to TC at AZO is higher than at AVE. The presence of diacids in the marine atmosphere have been attributed either to long-range transport from industrialized continents or in situ photochemical production but the respective contribution of the two sources have not yet been examined on seasonal basis. 

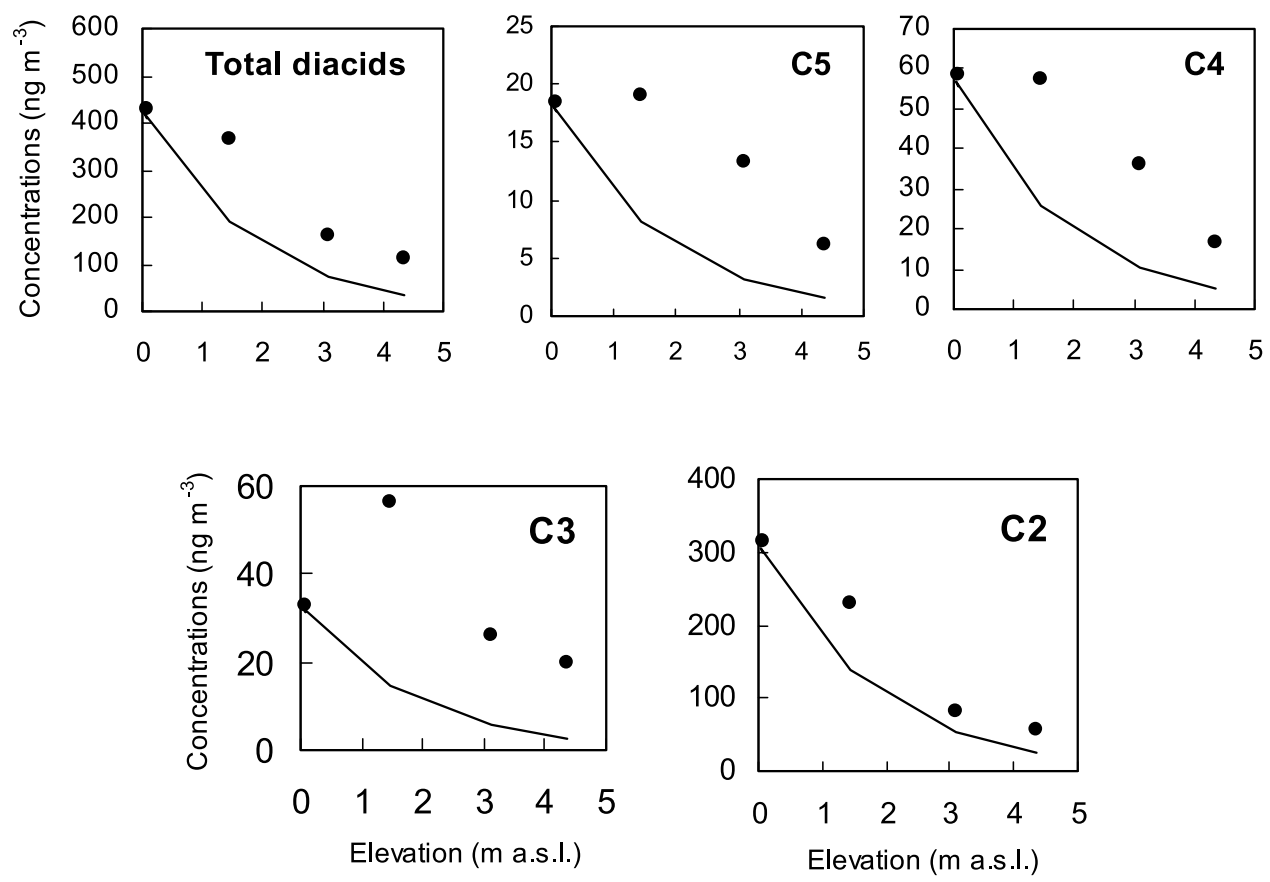

Figure 5. Decrease of total diacids and individual species versus elevation under midsummer conditions (June-August). C2 is oxalic, C3 is malonic, C4 is succinic plus malic, and C5 is glutaric acid. The solid lines refer to the expected change with elevation for a primarily emitted species (see text).

[41] In winter, the level of total carbon (TC) decreases from $8.8 \mu \mathrm{g} \mathrm{C} \mathrm{m}^{-3}$ at AVE to $0.3 \mu \mathrm{g} \mathrm{C} \mathrm{m}^{-3}$ at AZO whereas total diacids are only decreased by a factor of 10 between the two sites. The decrease between AVE and AZO is even weaker for short-chain diacids (a factor of 5 to 7 for $\mathrm{C} 2$ and $\mathrm{C} 3$ ) than for long-chain diacids (a factor of 12 to 15 for $\mathrm{C} 4$ and C5) (Table 2). The linear relationships between oxalic acid and longer-chain diacids at AVE differ from those observed at AZO (Table 3). First, in contrast to what is observed at AVE, they indicate a quasi-zero y-intercept. Second, the slope of the linear correlation between oxalic and glutaric acid is 3 times higher at AZO than at AVE. That suggests that aging of air masses during transport have favored the production of short-chain diacids, the successive oxidations of $\mathrm{C} 5$ and $\mathrm{C} 4$ which have not efficiently acted over continents (see section 4.1) have had time enough there to proceed until total depletion of $\mathrm{C} 5$ and $\mathrm{C} 4$ diacids. This ongoing oxidation during the transport is also supported by the succinic to malic ratio which is lower at AZO (0.8) than at AVE (1.4) in winter (Table 3). The observed abundance of diacids at AZO relative to continental sites therefore suggests that secondary production of diacids have continued in air masses advected from the continents in winter. Furthermore the quasi-zero y-intercept of the relationship between oxalic acid and malonic acid at AZO (Table 3) suggest that no oxalic acid is produced there from glyoxylic acid in winter.

[42] With respect to TC, diacids are more abundant in summer than in winter (Figure 7). If we assume that the presence of TC at the Azores is mainly related to long-range transport from continents and that the contribution of diacids to $\mathrm{TC}$ of this long-range transported input remains similar in winter and summer, it can be concluded that there are additional sources of diacids at AZO in summer. In contrast to winter, the y-intercepts of linear relationships
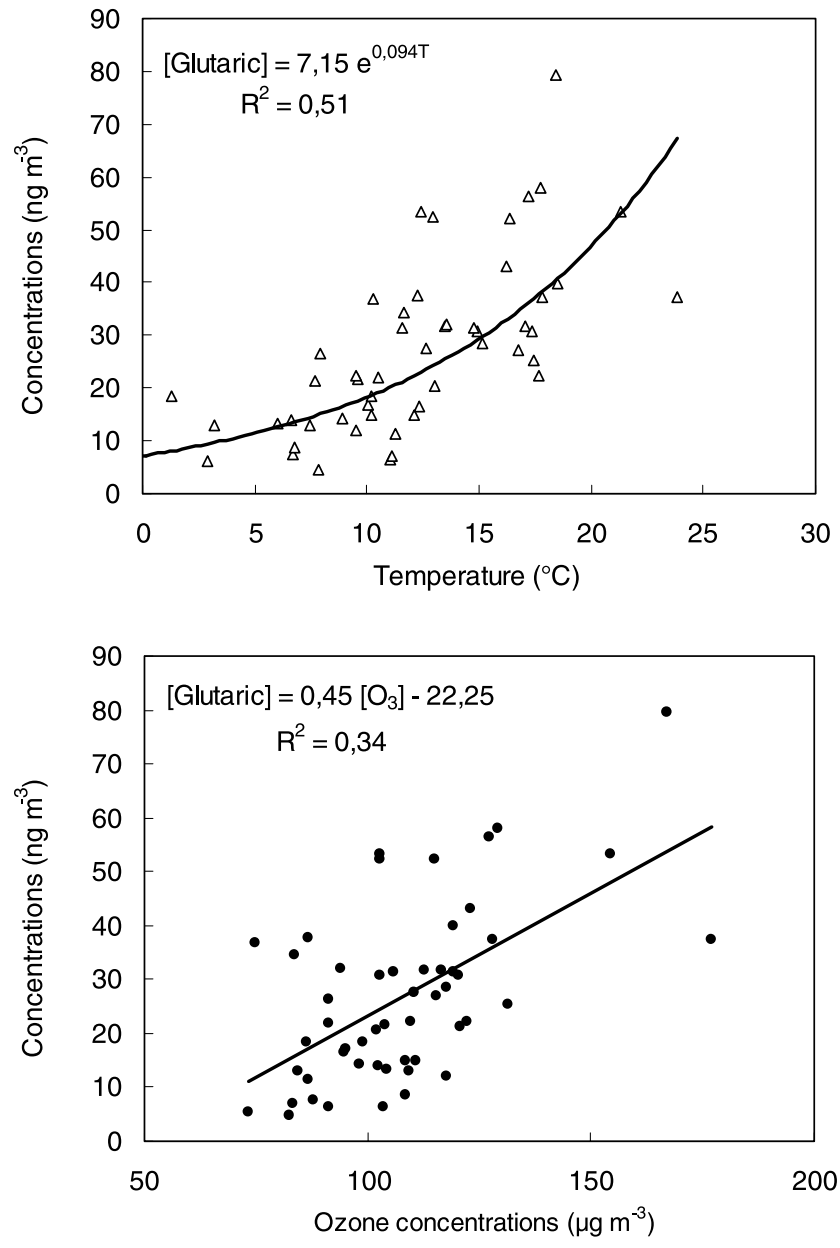

Figure 6. Gluratic acid level versus mean temperature (T) and ozone concentration at SIL from April to October. 



Figure 7. Monthly mean levels at AZO of (a) total diacids, (b) oxalic acid, (c) glutaric acid, and (d) C4 diacids (open triangles, right scale in $\mathrm{ng} \mathrm{m}^{-3}$ ) versus TC (solid circles, left scale in $\mu \mathrm{g} \mathrm{C} \mathrm{m}^{-3}$ ). Monthly mean levels at AZO of (e) sodium and (f) MSA (in $\mathrm{ng} \mathrm{m}^{-3}$ ).

between oxalic acid and longer-chain diacids at AZO differ from zero in summer (Table 3). This observation supports the preceding assumption that in addition to the long-range transport from continents which mainly explains the presence of all diacids in winter at AZO, other sources of diacids exist there in summer. If not we would expect an increase of the slope for the different relationships between oxalic acid and longer-chain diacids in summer compared to winter and that is not the case as seen in Table 3. Unsaturated fatty acids such as linoleic and oleic acids, that are common in phytoplankton, were detected in aerosol at AZO, particularly in summer [Oliveira et al., 2007]. They may act as precursors of $\mathrm{C} 4$ and $\mathrm{C} 5$ diacids at $\mathrm{AZO}$ in summer.

[43] The y-intercept of the linear relationship between oxalic and malonic acid in summer (35 $\mathrm{ng} \mathrm{m}^{-3}$, Table 3 ) suggests that, in addition to the oxidation of $\mathrm{C} 3-\mathrm{C} 5$ diacids into oxalic acid, another source of oxalic acid exists. Ethene emitted from the marine biosphere may act as a precursor of oxalic acid via the aqueous phase oxidation of glyoxal and hydroxyacetaldehyde into glyoxylic acid thereafter oxidized into oxalic acid (Figure 2). Warneck [2003] estimated that in the marine atmosphere 8 to $16 \mathrm{ng} \mathrm{m}^{-3}$ of oxalic acid may be produced by the oxidation of ethene. 
[44] As seen in Figure 7 there are some differences in the temporal recovery of summer level of diacids. Whereas C4-C5 diacids peak in May-June, oxalic acid remains high from April to September. Such a difference is not a surprise given the two processes here involved. Unsaturated fatty acids are emitted into the atmosphere with sea-salt particles whereas gaseous emissions of ethene are thought to be related to the presence of dissolved organic material released in seawater by algae then photochemically transformed into alkenes [Ratte et al., 1998]. Emissions of unsaturated fatty acids would accompany sea-salt emissions which are higher in spring than in summer as suggested by sodium levels (Figure 7). Emissions of ethene are controlled by radiations which are larger during the entire summer period. Note that the level of total diacids sometimes largely exceeds that of MSA (Figure 7) which is interesting because, in addition to sulfur species derived from DMS oxidation, these highly water soluble organic diacids may contribute to $\mathrm{CCN}$ mass in the marine atmosphere.

[45] In conclusion this year-round study of diacids at a marine site suggests that, in addition to secondary production of diacids during transport of air masses advected from continents, unsaturated fatty acids from phytoplankton emitted with sea salt and ethene produced by photooxidation of dissolved organic carbon represent a local source of diacids in summer.

\section{Conclusions}

[46] A two-year-round climatology of $\mathrm{C}_{2}-\mathrm{C}_{5}$ diacids obtained in Europe was discussed versus environmental conditions at sites (marine/continental, rural/forested, boundary layer/free troposphere, and winter/summer). Backed up by additional investigations on radioisotope $\left({ }^{210} \mathrm{~Pb}\right)$, inorganic fractions (anthropogenic sulfate, and fine fraction of primarily emitted potassium), and organic compounds (total organic carbon, n-alkanes, levoglucosan) the diacid observations have been used to highlight their origins. Continental surface sites seem to be influenced in winter by fast production of $\mathrm{C} 2-\mathrm{C} 5$ diacids in wood burning plumes, and secondary aqueous phase production of oxalic acid from aldehydes formed by the rapid oxidation of toluene and ethene emitted by cars. Whereas $\mathrm{C} 3-\mathrm{C} 5$ diacids seem to come mainly from wood burning plumes, it is suggested that around two thirds of $\mathrm{C} 2$ are related to this source and one third of $\mathrm{C} 2$ to secondary production from toluene and ethene vehicular emissions. In summer, vehicular emissions and wood burning plumes are more efficiently dispersed from the boundary layer and emissions from larger scale become important. It is suggested that $30-40 \%$ of $\mathrm{C} 2$ are related to aqueous production from biogenic precursors (isoprene and acetic acid emitted by vegetation). The presence of $\mathrm{C} 3-\mathrm{C} 5$ diacids and of the left fraction of oxalic acid is less clear, likely related to other biogenic precursors (unsaturated fatty acids and oxygenated volatile organic compounds). Further works are here needed to evaluate possible aqueous phase production of oligomers from products of monoterpene oxidation. Observations support the suggested aqueous oxidation of longer into shorter diacids. These reactions which mainly take place in summer are slower than the oxidation of $\mathrm{SO}_{2}$ into sulfate, leading to an enrichment of diacids in aerosol in the free troposphere. Diacids present at the Azores are not only related to long-range transport from continents but also to in situ productions from precursors emitted by the marine biosphere (particulate unsaturated fatty acids and ethene) in summer. Finally, whatever the season and the site, secondary aqueous phase productions always appear important for the budget of diacids. That stimulates further studies of these liquid phase reactions since other species like oligomers, which might contribute more to aerosol mass, are here suspected to be produced as well.

[47] Acknowledgments. The project was funded by EU contract EVK2 CT2001-00113. The authors acknowledge the contribution of many members of the CARBOSOL team for sampling, sample handling and transfer. The authors would like to thank the three anonymous reviewers for their helpful comments on the manuscript and Barbara Ervens and Kimitaka Kawamura for helpful discussions.

\section{References}

Altieri, K. E., A. G. Carlton, H.-J. Lim, B. J. Turpin, and S. P. Seitzinger (2006), Evidence for oligomer formation in clouds: Reactions of isoprene oxidation products, Environ. Sci. Technol., 40, 4956-4960.

Ariya, P. A., O. Nepotchatykh, O. Ignatova, and M. Amyor (2002), Microbiological degradation of atmospheric organic compounds, Geophys. Res. Lett., 29(22), 2077, doi:10.1029/2002GL015637.

Cachier, H., J. Ducret, M. P. Bremond, A. Gaudichet, J. P. Lacaux, V. Yoboue, and J. Baudet (1991), Characterisation of biomass burning aerosols in savanna region of the Ivory Coast, in Global Biomass Burning, edited by J. Levine, pp. 174-180, MIT Press, Cambridge, Mass.

Carlton, A. G., B. J. Turpin, H.-J. Lim, K. E. Altieri, and S. Seitzinger (2006), Link between isoprene and secondary organic aerosol (SOA): Pyruvic acid oxidation yields low volatility organic acids in clouds, Geophys. Res. Lett., 33, L06822, doi:10.1029/2005GL025374.

Cruz, C. N., and S. N. Pandis (1997), A study of the ability of secondary organic aerosol to act as cloud condensation nuclei, Atmos. Environ., 31, $2205-2214$

Cruz, C. N., and S. N. Pandis (1998), The effect of organic coatings on the cloud condensation nuclei activation of inorganic atmospheric aerosol, J. Geophys. Res., 103, 13,111-13,123.

Ervens, B., et al. (2003a), CAPRAM 2.4 (MODAC mechanism): An extended and condensed tropospheric aqueous phase mechanism and its application, J. Geophys. Res., 108(D14), 4426, doi:10.1029/2002JD002202.

Ervens, B., S. Gligorovski, and H. Herrmann (2003b), Temperature-dependent rate constants for hydroxyl radical reactions with organic compounds in aqueous phase, Phys. Chem. Chem. Phys., 5, 1811-1824.

Ervens, B., G. Feingold, G. J. Frost, and S. M. Kreidenweis (2004), A modeling study of aqueous production of dicarboxylic acids: 1. Chemical pathways and speciated organic mass production, J. Geophys. Res., 109, D15205, doi:10.1029/2003JD004387.

Gao, S., D. A. Hegg, P. V. Hobbs, T. W. Kirchstetter, B. I. Magi, and M. Sadilek (2003), Water-soluble organic components in aerosols associated with savanna fires in southern Africa: Identification, evolution, and distribution, J. Geophys. Res., 108(D13), 8491, doi:10.1029/ 2002JD002324.

Griffin, R. J., D. R. Cocker III, R. C. Flagan, and J. H. Seinfeld (1999), Organic aerosol formation from the oxidation of biogenic hydrocarbons, J. Geophys. Res., 104, 3555-3567.

Grosjean, D. (1989), Organic acids in southern California air: Ambient concentrations, mobile source emissions, in situ formation and removal processes, Environ. Sci. Technol., 23, 1506-1514.

Hammer, S., D. Wagenbach, S. Preunkert, C. Pio, and F. Meinhardt (2007), Observations of ${ }^{210} \mathrm{~Pb}$ within CARBOSOL: A diagnostic tool for assessing the spatiotemporal variability of related chemical aerosol species? J. Geophys. Res., doi:10.1029/2006JD008065, in press.

Hatakeyama, S., T. Tanonaka, J. Weng, H. Bandow, H. Takagi, and H. Akimoto (1985), Ozone-cyclohexene reaction in air: Quantitative analyses of particulate products and the reaction mechanism, Environ. Sci. Technol., 19, 935-942.

Kalberer, M., J. Yu, D. R. Cocker, R. C. Flagan, and J. H. Seinfeld (2000), Aerosol formation in the cyclohexene-ozone system, Environ. Sci. Technol., 34, 4894-4901.

Kawamura, K., and R. B. Gagosian (1987), Implications of $\omega$-oxocarboxylic acids in the remote atmosphere for photo-oxidation of unsaturated fatty acids, Nature, 325, 330-332.

Kawamura, K., and K. Ikushima (1993), Seasonal changes in the distribution of dicarboxylic acids in the urban atmosphere, Environ. Sci. Technol., 27, 2227-2235. 
Kawamura, K., and I. R. Kaplan (1987), Motor exhaust emissions as primary source for dicarboxylic acids in Los Angeles ambient air, Environ. Sci. Technol., 21, 105-110.

Kawamura, K., and F. Sakaguchi (1999), Molecular distribution of water soluble dicarboxylic acids in marine aerosols over the Pacific Ocean including tropics, J. Geophys. Res., 104, 3501-3509.

Kawamura, K., and K. Usukura (1993), Distributions of low molecular weight dicarboxylic acids in the north Pacific aerosol samples, J. Oceanogr., 49, 271-283.

Kerminen, V.-M., C. Ojanen, T. Pakkanen, R. Hillamo, M. Aurela, and J. Meriläinen (2000), Low-molecular-weight dicarboxylic acids in an urban and rural atmosphere, J. Aerosol Sci., 31, 349-362.

Kesselmeier, J., and M. Staudt (1999), Biogenic volatile organic compounds (VOC): An overview on emission, physiology, and ecology, J. Atmos. Chem., 33, 23-88.

Legrand, M., and H. Puxbaum (2007), Summary of the CARBOSOL project: Present and retrospective state of organic versus inorganic aeroso over Europe, J. Geophys. Res., doi:10.1029/2006JD008271, in press.

Legrand, M., S. Preunkert, D. Wagenbach, H. Cachier, and H. Puxbaum (2003), A historical record of formate and acetate from a high-elevation Alpine glacier: Implications for their natural versus anthropogenic budgets at the European scale, J. Geophys. Res., 108(D24), 4788 , doi:10.1029/2003JD003594.

Legrand, M., S. Preunkert, C. Galy-Lacaux, C. Liousse, and D. Wagenbach (2005), Atmospheric year-round records of dicarboxylic acids and sulfate at three French sites located between 630 and $4360 \mathrm{~m}$ elevation, J. Geophys. Res., 110, D13302, doi:10.1029/2004JD005515.

Lim, H.-J., A. G. Carlton, and B. J. Turpin (2005), Isoprene forms secondary organic aerosol through cloud processing: Model simulations, Environ. Sci. Technol., 39, 4441-4446.

Limbeck, A., and H. Puxbaum (1999), Organic acids in continental background aerosols, Atmos. Environ., 33, 1847-1852.

Mader, B. T., J. Z. Yu, J. H. Xu, Q. F. Li, W. S. Wu, R. C. Flagan, and J. H. Seinfeld (2004), Molecular composition of the water-soluble fraction of atmospheric carbonaceous aerosols collected during ACE-Asia, J. Geophys. Res., 109, D06206, doi:10.1029/2003JD004105.

Matsunaga, S., K. Kawamura, T. Nakatsuka, and N. Ohkouchi (1999), Preliminary study on laboratory photochemical formation of low weight dicarboxylic acids from unsaturated fatty acid (oleic acid), Res. Org. Geochem., 14, 19-25.

Oliveira, T. S., C. A. Pio, C. A. Alves, A. J. D. Silvestre, M. Evtyugina, J. V. Afonso, P. Fialho, M. Legrand, H. Puxbaum, and A. Gelencser (2007), Seasonal variation of particulate lipophilic organic compounds at nonurban sites in Europe, J. Geophys. Res., doi:10.1029/2007JD008504, in press.

Pio, C. A., et al. (2007), Climatology of aerosol composition (organic versus inorganic) at non-urban areas on a west-east transect across Europe, J. Geophys. Res., doi:10.1029/2006JD008038, in press

Preunkert, S., M. Legrand, and D. Wagenbach (2001), Sulfate trends in a Col du Dôme (French Alps) ice core: A record of anthropogenic sulphate levels in the European midtroposphere over the twentieth century, J. Geophys. Res., 106, 31,991-32,004

Preunkert, S., D. Wagenbach, and M. Legrand (2002), Improvement and characterization of an automatic aerosol sampler at high-Alpine drilling sites, Atmos. Environ., 36, 1221-1232.

Puxbaum, H., A. Caseiro, A. Sanchez-Ochoa, A. Kasper-Giebl, M. Claeys, A. Gelencser, M. Legrand, S. Preunkert, and C. Pio (2007), Levoglucosan levels at background sites in Europe for assessing the impact of biomass combustion on the European aerosol background, J. Geophys. Res. doi:10.1029/2006JD008114, in press.
Ratte, M., O. Bulok, A. Spitzy, and J. Rudolph (1998), Photochemical alkene formation in seawater from dissolved organic carbon: Results from laboratory experiments, J. Geophys. Res., 103, 5707-5715.

Ricard, V., J.-L. Jaffrezo, V.-M. Kerminen, R. E. Hillamo, M. Sillanpaa, S. Ruellan, C. Liousse, and H. Cachier (2002), Two years of continuous aerosol measurements in northern Finland, J. Geophys. Res., 107(D11), 4129, doi:10.1029/2001JD000952.

Rogge, W. F., L. M. Hildemann, M. A. Mazurek, G. R. Cass, and B. R. T. Simoneit (1991), Sources of fine organic aerosol. 1. Charbrollers and meat cooking operations, Environ. Sci. Technol., 25, 1112-1125.

Rogge, W. F., M. A. Mazurek, L. M. Hildemann, and G. R. Cass (1993), Quantification of urban organic aerosol at a molecular level: Identification, abundance and seasonal variation, Atmos. Environ., 27, 1309-1330.

Rogge, W. F., L. M. Hildemann, M. A. Mazurek, G. R. Cass, and B. R. T. Simoneit (1998), Sources of fine organic aerosol. 9. Pine, oak, and synthetic log combustion in residential fireplaces, Environ. Sci. Technol., 32, $13-22$

Röhrl, A., and G. Lammel (2001), Low-molecular weight dicarboxylic acids and glyoxylic acid: Seasonal and air mass characteristics, Environ. Sci. Technol., 35, 95-101.

Saxena, P., and L. M. Hildemann (1996), Water-soluble organics in atmospheric particles: A critical review of the literature and application of thermodynamics to identify candidate compounds, J. Atmos. Chem., 24, 57-109.

Schauer, J. J., W. F. Rogge, L. M. Hildemann, M. A. Mazurek, and G. R. Cass (1996), Source apportionment of airborne particulate matter using organic compounds as tracers, Atmos. Environ., 30, 3837-3855.

Sempéré, R., and K. Kawamura (2003), Trans-hemispheric contribution of $\mathrm{C}_{2}-\mathrm{C}_{10} \alpha$, $\omega$-dicarboxylic acids, and related polar compounds to watersoluble organic carbon in the western Pacific aerosols in relation to photochemical oxidation reactions, Global Biogeochem. Cycles, 17(2), 1069, doi:10.1029/2002GB001980.

Sillanpää, S., S. Saarikoski, R. Hillamo, A. Pennanen, U. Makkonen, Z. Spolnik, R. Van Grieken, T. Koskentalo, and R. Salonen (2005), Chemical composition, mass size distribution and sources analysis of longrange transported wildfire smokes in Helsinki, Sci. Total Environ., 350, $119-135$.

Simpson, S., A. Guenther, C. N. Hewitt, and R. Steinbrecher (1995), Biogenic emissions in Europe: 1. Estimates and uncertainties, J. Geophys. Res., 100, 22,875-22,890.

Simpson, S., et al. (1999), Inventorying emissions from nature in Europe, J. Geophys. Res., 104, 8113-8152.

Warneck, P. (2003), In-cloud chemistry opens pathway to the formation of oxalic acid in the marine atmosphere, Atmos. Environ., 37, 2423-2427.

A. Gelencsér, Air Chemistry Group of the Hungarian Academy of Sciences, University of Pannonia, Egyetem u. 10, H-8200 Veszprém, Hungary.

S. Hammer, Institut fur Umweltphysik, Ruprecht Karls-Universitat Heidelberg, D-69120 Heidelberg, Germany.

A. Kasper-Giebl, Institute for Chemical Technologies and Analytics, Vienna University of Technology, Getreidemarkt 9/164-UPA, A-1060 Vienna, Austria.

P. Laj, Laboratoire de Météorologie Physique, Centre National de la Recherche Scientifique, Université Blaise Pascal, 24 Avenue des Landais, F-63177 Aubière cedex, France.

M. Legrand and S. Preunkert, Laboratoire de Glaciologie et Géophysique de l'Environnement, Centre National de la Recherche Scientifique, St. Martin d'Hères F-38402, France. (legrand@1gge.obs.ujf-grenoble.fr)

T. Oliveira and C. A. Pio, Departamento de Ambiente e Ordenamento, Universidade de Aveiro, 3810-193 Aveiro, Portugal. 